\title{
Concentration and estimated flow of soluble non-ammonia nitrogen entering the omasum of dairy cows as influenced by different protein supplements
}

\author{
ChangWeon Choi, Aila Vanhatalo and Pekka Huhtanen \\ MTT Agrifood Research Finland, Animal Production Research, FIN-31600 Jokioinen, Finland, \\ e-mail: chang-weon.choi@mtt.fi
}

\begin{abstract}
Four ruminally fistulated Finnish Ayrshire cows were used to study the effects of different protein supplements on concentration and flow of soluble non-ammonia N (SNAN) into the omasum. The treatments in a $4 \times 4$ Latin square design were a basal diet of grass silage and barley and the basal diet supplemented with fishmeal, soybean meal and maize gluten meal. Protein supplements significantly increased concentrations of peptide $\mathrm{N}(\mathrm{P}=0.009)$ and total SNAN $(\mathrm{P}=0.03)$ fractions in omasal digesta. Peptide constituted the largest proportion of SNAN flow into the omasum indicating that hydrolysis of peptides to amino acids is the most limiting step in rumen proteolysis. The microbial contribution to SNAN was on an average 0.64 indicating that a large proportion of SNAN flow leaving the rumen was of microbial origin. The estimated SNAN flow per kg dry matter intake from the basal diet and protein supplemented diets indicated that approximately 49, 22 and $37 \mathrm{~g} \mathrm{~kg}^{-1}$ of fishmeal, soybean meal and maize gluten meal protein, respectively, escaped from ruminal degradation as SNAN.
\end{abstract}

Key words: soluble non-ammonia nitrogen, protein supplements, omasum, dairy cows, peptides

\section{Introduction}

Ruminal protein degradability is typically assessed by in situ method, which assumes that the rapidly degradable nitrogen $(\mathrm{N})$ (a-fraction) is degraded at an infinite rate, and consequently that only insoluble feed $\mathrm{N}$ can escape ruminal degradation. However, relatively high concentrations of soluble non-ammonia N (SNAN) consisting of free amino acid (AA), peptide and soluble protein, in rumen fluid (Chen et al. 1987a,
Robinson and McQueen 1994) or omasal digesta (Choi et al. 2002a, b) suggest that a proportion of protein can escape rumen degradation in the liquid phase. Broderick (1987) reported using in vitro system that the degradation rate of casein $\mathrm{N}$ was $0.40-0.60 \mathrm{~h}^{-1}$, also suggesting that a considerable portion of casein $\mathrm{N}$ can escape ruminal degradation. Consequently, the assumption of in situ method may be invalid. When skimmed milk powder was used as a protein supplement for dairy cows, the SNAN concentration in omasal digesta was $110 \mathrm{mg} \mathrm{N}^{-1}$ (Choi et 
Choi, C.W. et al. Protein response to omasal soluble non-ammonia nitrogen

al. 2002b). Assuming a rumen volume of 80 litres and a liquid passage rate of $0.15 \mathrm{~h}^{-1}$, approximately $32 \mathrm{~g} \mathrm{~N} \mathrm{~d}^{-1}$ of SNAN could potentially escape the rumen. It was calculated that $116 \mathrm{~g}$ $\mathrm{kg}^{-1}$ of skimmed milk powder $\mathrm{N}$ escaped ruminal degradation as SNAN in dairy cows fed a grass silage based diet (Choi et al. 2002b). However, the value was not corrected for microbial contamination.

Few dietary data on the concentration and the estimated flow of SNAN from the rumen and/or the omasal canal of ruminant animals have been reported. When dairy cows were given grass silage based diet, inclusion of rapeseed meal increased the concentration of SNAN in the liquid phase of the omasal digesta (Choi et al. 2002a). Chen et al. (1987b) reported that high concentration of peptide $\mathrm{N}$ accumulated in the rumen when untreated soybean meal was given. However, when treated soybean meal was given the peptide $\mathrm{N}$ concentration decreased even though the concentration was still relatively high (Chen et al. 1987b). Peptide N concentration varied when different protein supplements were given to steers, but it was poorly correlated with degradability and solubility of the supplements (Williams and Cockburn 1991). More recently, our study (Choi et al. 2002b) also showed that omasal SNAN did not depend on the type of protein supplements although it was increased by all protein supplements. However, some of the supplements used in the experiment (skimmed milk powder and wet distiller's solubles) are not commonly used in practice.

The present experiment was designed to study effects of more widely used protein supplements on the concentration and the estimated flow of SNAN escaping ruminal degradation in dairy cows fed grass silage based diets. Furthermore, because a proportion of SNAN in the liquid phase was suggested to be of microbial origin (Choi et al. 2002a), we also determined the potential microbial contamination using ${ }^{15} \mathrm{~N}$ as a microbial marker. Data on nutrient flows and subsequent animal responses have been reported elsewhere (Korhonen et al. 2002).

\section{Material and methods}

\section{Experimental procedures}

Four Finnish-Ayrshire dairy cows (mean live weight, $668 \pm 109 \mathrm{~kg}$; days in milk, $51 \pm 6$ days) fitted with $10-\mathrm{cm}$ i.d. ruminal cannulas were used in a $4 \times 4$ Latin-square experiment with periods of $28 \mathrm{~d}$ including $4 \mathrm{~d}$ for omasal sampling. During an adaptation period (14 d) dry matter (DM) intake of each cow was recorded. On day 15, DM intake was then restricted to 0.95 of the ad libitum intakes. The basal diet $\left(\mathrm{kg} \mathrm{kg}^{-1} \mathrm{DM}\right)$ contained grass silage (0.55) and rolled barley concentrate (0.45) (Table 1). Part of DM intake of the basal diet (control) was isonitrogenously replaced by one of protein supplements as follows; fishmeal (0.06) (diet FM), soybean meal (0.09) (diet SBM) or maize gluten meal (0.06) (diet MGM). Each protein supplement replaced portions of both silage and barley such that the ratio of grass silage to barley $(55: 45)$ remained constant for all treatments. Mineral and vitamin mixture was given at a rate of $300 \mathrm{~g} \mathrm{~d}^{-1}$. Grass prepared from secondary growth of swards containing predominately timothy (Phleum pratense) and meadow fescue (Festuca pratensis) and cocksfoot (Dactylis glomerata) was ensiled in a tower silo with a formic acid-based additive (AIV-2+; Kemira-Agro, Helsinki, Finland) at a rate of $5 \mathrm{l} \mathrm{t}^{-1}$ of the grass. Barley was coarsely milled using a roller mill prior to feeding, and all protein supplements and mineral and vitamin mixture were purchased from commercial sources (Rehuraisio Ltd., Raisio; Suomen Rehu Ltd., Helsinki, Finland). The cows had a free access to water and salt block throughout the experiment. Feeds were offered twice daily at 0600 and 1800 and the cows were milked at 0700 and 1700.

\section{Sampling and chemical analyses}

Representative samples of grass silage and concentrate were collected over the last $10 \mathrm{~d}$ of each 
Vol. 11 (2002): 79-91.

Table 1. Proportion of dietary ingredients in experimental diet.

\begin{tabular}{lcccr}
\hline & \multicolumn{3}{c}{ Diet $^{\mathrm{a}}$} \\
\cline { 2 - 5 } & Control & FM & SBM & MGM \\
\hline Grass silage, $\mathrm{kg} \mathrm{kg}^{-1}$ dry matter & 0.55 & 0.52 & 0.50 & 0.52 \\
Barley concentrate, $\mathrm{kg} \mathrm{kg}^{-1}$ dry matter & 0.45 & 0.42 & 0.41 & 0.42 \\
Fishmeal, kg kg dry matter & & 0.06 & & \\
Soybean meal, $\mathrm{kg} \mathrm{kg}^{-1}$ dry matter & & & 0.09 & \\
Maize gluten meal, kg kg-1 dry matter & & & & 0.06 \\
\hline
\end{tabular}

a $\quad$ Control $=$ grass silage + barley; $F M=$ grass silage + barley + fishmeal; $\mathrm{SBM}=$ grass silage + barley + soybean meal; $\mathrm{MGM}=$ grass silage + barley + maize gluten meal. Each diet contained $300 \mathrm{~g} \mathrm{~d}^{-1}$ of mineral and vitamin mixture $\left(16 \%\right.$ of $\mathrm{Ca}, 6.4 \%$ of $\mathrm{P}, 9.0 \%$ of $\mathrm{Na}, 8.0 \%$ of $\mathrm{Mg}, 150,000 \mathrm{IU} \mathrm{kg}^{-1}$ of vitamin A, 100,000 IU kg-1 of vitamin D, $950 \mathrm{mg} \mathrm{kg}^{-1}$ of vitamin E, $530 \mathrm{mg} \mathrm{kg}^{-1}$ of Cu, $20 \mathrm{mg} \mathrm{kg}^{-1}$ of Se, $4200 \mathrm{mg} \mathrm{kg}^{-1}$ of $\mathrm{Zn}, 20 \mathrm{mg} \mathrm{kg}^{-1}$ of Mo, $15 \mathrm{mg} \mathrm{kg}^{-1}$ of Co, $2250 \mathrm{mg} \mathrm{kg}^{-1}$ of Mn and $140 \mathrm{mg} \mathrm{kg}^{-1}$ of I).

experimental period pooled over the period and stored at $-20^{\circ} \mathrm{C}$ until analysis. Details of analysis for chemical composition of feeds have previously been described by Ahvenjärvi et al. (2000). In brief, crude protein of feeds was determined using a Dumas-type N analyser (Leco FP-428; Leco Corporation, St Joseph, MI, USA). Soluble N content of silage was analysed using Kjeldahl method (Method No. 984.13; AOAC 1990). Neutral detergent fibre of feeds was assayed with $\alpha$-amylase and sodium sulphite, and was expressed without residual ash (Van Soest et al. 1991). Soluble $\mathrm{N}$ fractions (non-protein $\mathrm{N}$ (NPN) and soluble true protein N) of feeds were prepared and analysed as described by Licitra et al. (1996). In the fractionation of the feed NPN, free AA and peptide $\mathrm{N}$ were determined using ninhydrin (Choi et al. 2002a) while ammonia $\mathrm{N}$ was analysed using a colorimetric method (McCullough 1967).

Digesta flow into the omasum was estimated with a triple marker method (France and Siddons 1986) using indigestible neutral-detergent fibre, $\mathrm{Yb}$-acetate and LiCo-EDTA as markers for large particle, small particle and liquid phase, respectively. Doses of LiCo-EDTA (18 g) and Yb-acetate $(6 \mathrm{~g})$ were given at $60 \mathrm{~h}$ before the first sampling time, and then the markers were continuously infused into the rumen $\left(12 \mathrm{~g} \mathrm{~d}^{-1}\right.$ of LiCo-
EDTA and $4 \mathrm{~g} \mathrm{~d}^{-1} \mathrm{Yb}$-acetate). Microbial contribution to omasal SNAN was estimated using ammonium sulfate (Isotec Inc., Miamisburg, $\mathrm{OH}$, USA) with $10 \%$ enrichment of ${ }^{15} \mathrm{~N}\left(250 \mathrm{mg}{ }^{15} \mathrm{~N}\right.$ $\mathrm{d}^{-1}$ per cow) as a microbial marker. Infusion of the ${ }^{15} \mathrm{~N}$-enriched ammonium sulfate was started at $48 \mathrm{~h}$ before the first sampling.

To estimate the flow of SNAN fractions in the liquid phase of digesta, digesta entering the omasum was sampled according to the procedure described by Choi et al. (2002b). In brief, approximately $30 \mathrm{ml}$ of digesta was collected at 4$\mathrm{h}$ intervals during a $12-\mathrm{h}$ feeding cycle starting on day 25 of each period. On subsequent sampling days, the time of sampling was advanced by $1 \mathrm{~h}$ relative to the previous sampling day (i.e. totally 12 samples during 4 days). Details of the sample preparation have been described previously (Choi et al. 2002a) with a modification that a portion of each supernatant of the omasal digesta deproteonised with trichloroacetic acid was prepared with $10 \mathrm{~N} \mathrm{NaOH}$ to increase $\mathrm{pH}$ above 10 and incubated at $60^{\circ} \mathrm{C}$ for $10 \mathrm{~min}$ to eliminate ammonia. Residual ammonia in the omasal digesta was analysed using a colorimetric method (McCullough 1967). Different fractions (free AA, peptide and soluble protein) of SNAN within the omasal digesta were assessed using ninhydrin (Choi et al. 2002a). In brief, each frac- 
Choi, C.W. et al. Protein response to omasal soluble non-ammonia nitrogen

tion of SNAN in the omasal sample was estimated as follows: i) free AA as $\mathrm{N}$ from supernatant without acid-hydrolysis, ii) peptide as $\mathrm{N}$ from difference between hydrolysed supernatant $\left(6 \mathrm{M} \mathrm{HCl}\right.$ at $110^{\circ} \mathrm{C}$ for $24 \mathrm{~h}$ ) and free AA N and iii) protein as $\mathrm{N}$ from the hydrolysis of trichloroacetic acid-precipitate.

The ${ }^{15} \mathrm{~N}$-enrichement in the liquid phase of digesta entering the omasal canal was analysed as previously described by Choi et al. (2002a) with an exception that an oven $\left(60^{\circ} \mathrm{C}\right.$ for $\left.48 \mathrm{~h}\right)$ instead of a freeze-drying was used.

\section{Calculation and statistical analysis}

Since the ${ }^{15} \mathrm{~N}$-enrichment of ammonia was not measured, a calculation for ${ }^{15} \mathrm{~N}$-enrichment of the liquid phase was estimated assuming 0.70 of liquid associated bacteria (LAB)-NAN derived from ammonia $\mathrm{N}$ (Firkins et al. 1987). The details of calculations have been described by Choi et al. (2002a).

The rumen-escape of SNAN in the liquid phase of omasal digesta (eSNAN) from each protein supplement was calculated as follows:

$$
\begin{aligned}
\text { (1) } \mathrm{eSNAN}= & \left(\mathrm{SNAN}_{\text {supp }}-\mathrm{SNAN}_{\text {basal }}\right) \quad / \\
& \left(\mathrm{NI}_{\text {supp }}-\mathrm{NI}_{\text {basal }}\right)
\end{aligned}
$$

where $\mathrm{SNAN}_{\text {supp }}$ and $\mathrm{NI}_{\text {supp }}$ are the flow of SNAN in the liquid phase of omasal digesta and $\mathrm{N}$ intake for the protein supplemented diet, respectively, and $\mathrm{SNAN}_{\text {basal }}$ and $\mathrm{NI}_{\text {basal }}$ are the flow of SNAN in the liquid phase of omasal digesta and $\mathrm{N}$ intake for grass silage and barley concentrate in the protein supplemented diet, respectively. These are calculated as follows:

(2) $\mathrm{SNAN}_{\text {basal }}=\mathrm{SNAN}_{\text {cont }} \times \mathrm{DMI}_{\text {basal }} / \mathrm{DMI}_{\text {cont }}$

where $\mathrm{SNAN}_{\text {cont }}, \mathrm{DMI}_{\text {basal }}$ and DMI $\mathrm{Dm}_{\text {cont }}$ are the flow of SNAN in the liquid phase of omasal digesta for control diet, DM intake as grass silage and barley concentrate in the protein supplemented diet and DM intake in control diet excluding mixture of vitamin and mineral, respectively. Finally,
(3) $\mathrm{NI}_{\text {basal }}=\mathrm{NI}_{\text {cont }} \times \mathrm{DMI}_{\text {basal }} / \mathrm{DMI}_{\text {cont }}$

where $\mathrm{NI}_{\text {cont }}$ is $\mathrm{N}$ intake in control diet.

Data for feed $\mathrm{N}$ intake, liquid flow and total NAN were analysed with the GLM procedure of SAS (1996) according to the following statistical model:

(4) $Y_{i j k}=\mu+A_{i}+P_{j}+D_{k}+e_{i j k}$

where $\mathrm{A}, \mathrm{P}$ and $\mathrm{D}$ are animal, period, diet effects, respectively.

Data obtained from ammonia $\mathrm{N}$ and concentration and flow of SNAN determined at each sampling interval were analysed with the MIXED procedure of SAS (1996) for repeated measures according to the following statistical model:

(5) $\begin{aligned} \mathrm{Y}_{\mathrm{ijkl}}= & \mu+\mathrm{A}_{\mathrm{i}}+\mathrm{P}_{\mathrm{j}}+\mathrm{D}_{\mathrm{k}}+\mathrm{e}_{\mathrm{ijk}}+\mathrm{T}_{1}+(\mathrm{A} \times \mathrm{T})_{\mathrm{il}}+ \\ & (\mathrm{P} \times \mathrm{T})_{\mathrm{j} 1}+(\mathrm{D} \times \mathrm{T})_{\mathrm{k} 1}+\mathrm{e}_{\mathrm{ijkl}}\end{aligned}$

where $\mathrm{T}$ is time effect, and $\mathrm{A} \times \mathrm{T}, \mathrm{P} \times \mathrm{T}$ and $\mathrm{D} \times \mathrm{T}$ are animal by time, period by time and diets by time interactions, respectively. Animal effect, animal by time interaction and error terms $\left(\mathrm{e}_{\mathrm{ijk}}\right.$ defined as between unit error and $\mathrm{e}_{\mathrm{ijkl}}$ as within unit error) are multivariate normally distributed random effects with AR (1) covariance structure. Orthogonal contrasts used in postANOVA comparisons were as follows; 1) effect of protein supplement (control versus protein supplements), 2) comparison between animal and plant proteins (FM versus SBM + MGM) and 3) comparison between plant proteins (SBM versus MGM).

\section{Results}

\section{Feed composition, intake and digesta flow into the omasal canal}

The chemical composition and the soluble $\mathrm{N}$ fractions of experimental feeds are shown in Table 2. Fishmeal had relatively high free AA, peptide and soluble protein $\mathrm{N}$ but extremely low 
Vol. 11 (2002): 79-91.

Table 2. Chemical composition of experimental feeds.

\begin{tabular}{|c|c|c|c|c|c|}
\hline & Grass silage & Barley & Fishmeal & Soybean meal & $\begin{array}{c}\text { Maize gluten } \\
\text { meal }\end{array}$ \\
\hline \multicolumn{6}{|l|}{ Component, $\mathrm{g} \mathrm{kg}^{-1}$ dry matter (DM) } \\
\hline $\mathrm{DM}, \mathrm{g} \mathrm{kg}^{-1}$ & 222 & 888 & 909 & 912 & 917 \\
\hline Organic matter & 914 & 973 & 881 & 940 & 969 \\
\hline Nitrogen & 21 & 22 & 122 & 75 & 108 \\
\hline Neutral detergent fibre & 506 & 189 & 134 & 112 & 60 \\
\hline Acid detergent fibre & 257 & 39 & 0 & 59 & 7 \\
\hline \multicolumn{6}{|l|}{ Feed soluble $\mathrm{N}$ fractions ${ }^{\mathrm{a}}, \mathrm{g} \mathrm{kg}^{-1}$ total $\mathrm{N}$} \\
\hline NPN & 453 & 126 & 107 & 42 & 61 \\
\hline Ammonia & 40.0 & 1.2 & 1.0 & 0.6 & 3.7 \\
\hline Free amino acid & 219 & 20 & 60 & 6 & 17 \\
\hline Peptide & 194 & 105 & 47 & 35 & 40 \\
\hline Soluble true protein $\mathrm{N}$ & 15 & 151 & 80 & 163 & 9 \\
\hline \multicolumn{6}{|l|}{ Silage fermentation quality } \\
\hline $\mathrm{pH}$ & 4.00 & & & & \\
\hline Lactic acid, $\mathrm{g} \mathrm{kg}^{-1} \mathrm{DM}$ & 12.2 & & & & \\
\hline Acetic acid, $\mathrm{g} \mathrm{kg}^{-1} \mathrm{DM}$ & 9.77 & & & & \\
\hline Water soluble carbohydrate, $\mathrm{g} \mathrm{kg}^{-1} \mathrm{DM}$ & 146 & & & & \\
\hline Soluble $\mathrm{N}, \mathrm{g} \mathrm{kg}^{-1}$ total $\mathrm{N}$ & 458 & & & & \\
\hline
\end{tabular}

a Non-protein N (NPN) and soluble true protein N of feeds were determined according to Licitra et al. (1996), and each fraction of NPN was analysed using ninhydrin assay (Choi et al. 2002a).

ammonia $\mathrm{N}$ concentration. Peptide $\mathrm{N}$ in soybean meal and maize gluten meal was rather similar, but soybean meal contained more soluble protein $\mathrm{N}$ than maize gluten meal. Proportions of free AA in soluble N (NPN + soluble true protein $\mathrm{N}$ ) of feeds were $0.47,0.07,0.32,0.03$ and 0.24 for grass silage, barley, fishmeal, soybean meal and maize gluten meal, respectively, whereas peptide proportions were $0.41,0.38,0.25,0.17$ and 0.57 , respectively. Over half of the feed soluble $\mathrm{N}$ was in the form of free AA and peptide except for barley and soybean meal. Grass silage was restrictively fermented as indicated by relatively low concentrations of total acids and a low proportion of ammonia $\mathrm{N}$ in total $\mathrm{N}$.

Table 3 shows the DM intake of experimental feeds and liquid and total NAN flows into the omasal canal. The liquid flow into the omasal canal was not affected by dietary treatment (mean $200 \mathrm{ld}^{-1}$ ). However, the liquid flow tended to be higher for MGM than that for SBM
$(\mathrm{P}=0.08)$. Protein supplements increased total NAN flow entering the omasal canal $(\mathrm{P}=0.05)$ mainly as a result of increased total dietary NAN flow $(\mathrm{P}<0.001)$. Total NAN $(\mathrm{P}=0.04)$ and total dietary NAN flow $(\mathrm{P}<0.001)$ were higher in cows fed diet MGM than diet SBM.

\section{Soluble $\mathrm{N}$ entering the omasal canal}

\section{Concentration}

Protein supplements significantly increased the concentration of ammonia $\mathrm{N}$ in omasal digesta $(\mathrm{P}=0.006)$ (Table 4). The ammonia $\mathrm{N}$ concentration peaked at $2 \mathrm{~h}$ post-feeding (data not shown). Protein supplementation increased the ammonia $\mathrm{N}$ concentration compared to the control diet throughout the feeding cycle. Protein supplements significantly increased the concentrations of peptide $(\mathrm{P}=0.009)$ and total SNAN $(\mathrm{P}=0.03)$ fractions in omasal digesta. However, 


\section{Choi, C.W. et al. Protein response to omasal soluble non-ammonia nitrogen}

Table 3. Intake of dietary ingredients and effect of protein supplements on flow measurements into the omasal canal.

\begin{tabular}{|c|c|c|c|c|c|c|c|c|}
\hline & \multicolumn{4}{|c|}{ Diet $^{\mathrm{a}}$} & \multirow[b]{2}{*}{$\mathrm{SEM}^{\mathrm{b}}$} & \multicolumn{3}{|c|}{ Orthogonal contrasts ${ }^{\mathrm{c}}$} \\
\hline & Control & FM & SBM & MGM & & $\mathrm{C} 1$ & $\mathrm{C} 2$ & $\mathrm{C} 3$ \\
\hline \multicolumn{9}{|l|}{ Dry matter intake, $\mathrm{kg} \mathrm{d}^{-1}$} \\
\hline Grass silage & 10.9 & 10.7 & 10.2 & 10.5 & & & & \\
\hline Barley concentrate & 8.2 & 7.3 & 7.6 & 7.5 & & & & \\
\hline Fishmeal & & 1.0 & & & & & & \\
\hline Soybean meal & & & 1.8 & & & & & \\
\hline Maize gluten & & & & 1.1 & & & & \\
\hline Mineral and vitamin mixture & e 0.3 & 0.3 & 0.3 & 0.3 & & & & \\
\hline Total & 19.4 & 19.4 & 19.9 & 19.5 & 0.23 & & & \\
\hline Nitrogen, $\mathrm{g} \mathrm{d}^{-1}$ & 403 & 501 & 511 & 496 & 6.9 & $<0.001$ & 0.69 & 0.17 \\
\hline \multicolumn{9}{|l|}{ Omasal canal flow } \\
\hline Liquid, $1 \mathrm{~d}^{-1}$ & 210 & 199 & 182 & 209 & 9.1 & 0.25 & 0.75 & 0.08 \\
\hline Total NAN ${ }^{\mathrm{d}}, \mathrm{g} \mathrm{N} \mathrm{d}^{-1}$ & 358 & 396 & 368 & 413 & 11.2 & 0.05 & 0.95 & 0.04 \\
\hline Microbial NAN & 246 & 232 & 226 & 221 & 9.5 & 0.12 & 0.46 & 0.75 \\
\hline Dietary NAN & 112 & 164 & 142 & 192 & 4.6 & $<0.001$ & 0.55 & $<0.001$ \\
\hline
\end{tabular}

a $\quad$ Control $=$ grass silage + barley; $F M=$ grass silage + barley + fishmeal $; \mathrm{SBM}=$ grass silage + barley + soybean meal; MGM = grass silage + barley + maize gluten meal.

b $\mathrm{SEM}=$ standard error of the mean.

c $\mathrm{C} 1=$ control vs. other diets; $\mathrm{C} 2=\mathrm{FM}$ vs. SBM + MGM; C3 = SBM vs. MGM.

d Total NAN = total non-ammonia nitrogen.

Table 4. Effect of protein supplements on concentration $\left(\mathrm{mg} \mathrm{N}^{-1}\right)$ of ammonia N, soluble non-ammonia N (SNAN), soluble microbial non-ammonia N (SMNAN) and soluble dietary non-ammonia N (SDNAN) in the liquid phase of digesta entering the omasal canal.

\begin{tabular}{|c|c|c|c|c|c|c|c|c|}
\hline & \multicolumn{4}{|c|}{ Diet $^{\mathrm{a}}$} & \multirow[b]{2}{*}{$\mathrm{SEM}^{\mathrm{b}}$} & \multicolumn{3}{|c|}{ Orthogonal contrasts ${ }^{\mathrm{c}}$} \\
\hline & Control & FM & SBM & MGM & & $\mathrm{C} 1$ & $\mathrm{C} 2$ & $\mathrm{C} 3$ \\
\hline Ammonia $\mathrm{N}$ & 61.1 & 91.4 & 92.5 & 84.2 & 10.58 & 0.006 & 0.69 & 0.35 \\
\hline \multicolumn{9}{|l|}{ SNAN } \\
\hline Free amino acids & 13.5 & 16.9 & 16.8 & 18.9 & 3.73 & 0.37 & 0.84 & 0.69 \\
\hline Peptide & 56.0 & 81.0 & 78.4 & 72.8 & 9.74 & 0.009 & 0.40 & 0.44 \\
\hline Protein & 0.21 & 0.87 & 0.32 & 0.28 & 0.298 & 0.44 & 0.15 & 0.93 \\
\hline Total & 69.8 & 98.8 & 95.5 & 92.0 & 11.30 & 0.03 & 0.61 & 0.76 \\
\hline \multicolumn{9}{|l|}{ SMNAN } \\
\hline Total & 50.0 & 55.1 & 56.4 & 52.2 & 8.64 & 0.55 & 0.92 & 0.65 \\
\hline \multicolumn{9}{|l|}{ SDNAN } \\
\hline Total & 19.8 & 43.7 & 39.1 & 39.7 & 5.94 & 0.02 & 0.56 & 0.94 \\
\hline
\end{tabular}

a $\quad$ Control $=$ grass silage + barley $; \mathrm{FM}=$ grass silage + barley + fishmeal $; \mathrm{SBM}=$ grass silage + barley + soybean meal; MGM = grass silage + barley + maize gluten meal.

b $\mathrm{SEM}=$ standard error of the mean.

c $\mathrm{C} 1=$ control vs. other diets; $\mathrm{C} 2=\mathrm{FM}$ vs. SBM + MGM; C3 = SBM vs. MGM. 
Vol. 11 (2002): 79-91.

Table 5. Effect of protein supplements on flow $\left(\mathrm{g} \mathrm{N} \mathrm{d}^{-1}\right)$ of soluble non-ammonia $\mathrm{N}$ (SNAN), soluble microbial nonammonia N (SMNAN) and soluble dietary non-ammonia N (SDNAN) in the liquid phase of diegeta entering the omasal canal.

\begin{tabular}{|c|c|c|c|c|c|c|c|c|}
\hline & \multicolumn{4}{|c|}{ Diet $^{\mathrm{a}}$} & \multirow[b]{2}{*}{$\mathrm{SEM}^{\mathrm{b}}$} & \multicolumn{3}{|c|}{ Orthogonal contrasts ${ }^{\mathrm{c}}$} \\
\hline & Control & $\mathrm{FM}$ & SBM & MGM & & $\mathrm{C} 1$ & $\mathrm{C} 2$ & $\mathrm{C} 3$ \\
\hline \multicolumn{9}{|l|}{ SNAN } \\
\hline Free amino acids & 2.93 & 3.59 & 3.12 & 3.73 & 0.976 & 0.64 & 0.90 & 0.67 \\
\hline Peptide & 11.8 & 16.1 & 13.5 & 14.3 & 1.17 & 0.06 & 0.15 & 0.62 \\
\hline Protein & 0.05 & 0.15 & 0.06 & 0.06 & 0.048 & 0.45 & 0.15 & 0.96 \\
\hline Total & 14.7 & 19.8 & 16.7 & 18.1 & 1.73 & 0.12 & 0.29 & 0.59 \\
\hline \multicolumn{9}{|l|}{ SMNAN } \\
\hline Total & 10.7 & 10.6 & 9.6 & 10.1 & 1.12 & 0.69 & 0.58 & 0.74 \\
\hline \multicolumn{9}{|l|}{ SDNAN } \\
\hline Total & 4.08 & 9.16 & 7.11 & 7.96 & 1.403 & 0.05 & 0.37 & 0.67 \\
\hline
\end{tabular}

a $\quad$ Control $=$ grass silage + barley $; \mathrm{FM}=$ grass silage + barley + fishmeal; $\mathrm{SBM}=$ grass silage + barley + soybean meal; MGM = grass silage + barley + maize gluten meal.

b $\mathrm{SEM}=$ standard error of the mean.

c $\mathrm{C} 1=$ control vs. other diets; $\mathrm{C} 2=\mathrm{FM}$ vs. SBM + MGM; C3 = SBM vs. MGM.

there were not significant differences in SNAN fractions entering the omasal canal between the protein supplements. Approximately 0.64 of SNAN in the liquid phase of digesta was of microbial origin. Protein supplements did not affect microbial SNAN concentration whereas dietary SNAN concentration was significantly increased by the supplements $(\mathrm{P}=0.02)$.

Flow

Protein supplements tended to increase total SNAN $(\mathrm{P}=0.12)$ and peptide $\mathrm{N}$ flow $(\mathrm{P}=0.06)$ (Table 5). Approximately 0.80 of SNAN flow into the omasum was in the form of peptides, while free AA and protein $\mathrm{N}$ accounted for proportionately of 0.19 and 0.02 SNAN, respectively. The contribution of dietary SNAN to the total SNAN was $0.28,0.46,0.43$ and 0.44 for control, FM, SBM and MGM diets, respectively. The dietary SNAN flow significantly increased when protein supplements were given $(\mathrm{P}=0.05)$.

\section{Proportion of soluble $N$ in total NAN flow}

Examination of individual nitrogenous fractions in SNAN indicated that the proportion in the form of peptide present in total NAN was mark- edly higher than the other two fractions (Table 6). Mean proportions of free AA, peptide, protein and total SNAN were 8.6, 37.5, 0.23 and $46.3 \mathrm{~g} \mathrm{~kg}^{-1}$ total NAN, respectively.

Based on ${ }^{15} \mathrm{~N}$ enrichments, the proportions of microbial SNAN and dietary SNAN were on average 28.0 and $18.4 \mathrm{~g} \mathrm{~kg}^{-1}$ total NAN, respectively. The proportion of microbial SNAN in total microbial NAN was on an average $46.4 \mathrm{~g} \mathrm{~kg}^{-}$ ${ }^{1}$, whereas the proportion of dietary SNAN in total dietary NAN was $46.8 \mathrm{~g} \mathrm{~kg}^{-1}$. Protein supplements increased the proportion of dietary SNAN in total NAN flow $(\mathrm{P}=0.03)$.

\section{Diurnal variation in SNAN}

Diurnal variations in SNAN and dietary SNAN only tended to be influenced by diet $x$ time interaction $(\mathrm{P}<0.10)$. Mean diurnal pattern of SNAN fractions for the experimental diets are shown in Fig. 1. Mean peptide $N$ peaked at $1-3$ $\mathrm{h}$ post-feeding and declined thereafter, while the peak of mean free AA was shown only at $1 \mathrm{~h}$ post-feeding. Soluble protein $\mathrm{N}$ concentration was very low and remained relatively constant throughout the feeding cycle. Diurnal pattern of free AA $(\mathrm{P}=0.02)$ and peptide $(\mathrm{P}=0.005)$ frac- 
Choi, C.W. et al. Protein response to omasal soluble non-ammonia nitrogen

Table 6. Effect of protein supplements on the proportion $\left(\mathrm{g} \mathrm{kg}^{-1}\right)$ of soluble non-ammonia N (SNAN), soluble microbial non-ammonia N (SMNAN) and soluble dietary non-ammonia N (SDNAN) in the liquid phase of omasal digesta in total non-ammonia $\mathrm{N}(\mathrm{NAN})$.

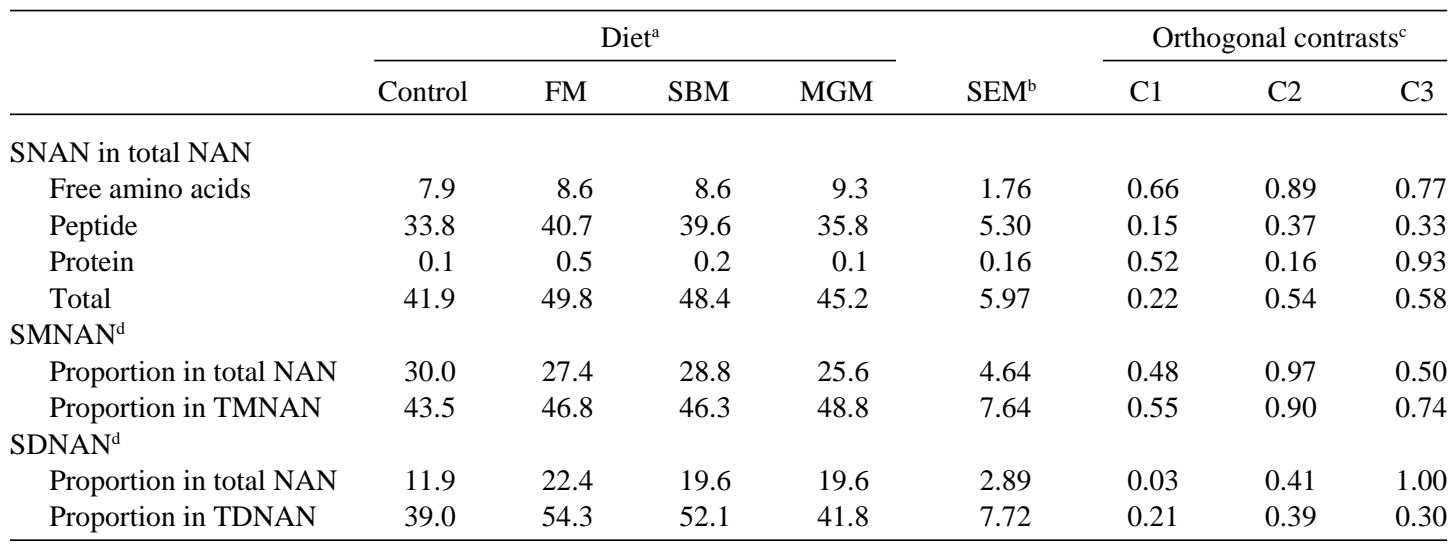

a $\quad$ Control $=$ grass silage + barley $; \mathrm{FM}=$ grass silage + barley + fishmeal $; \mathrm{SBM}=$ grass silage + barley + soybean meal; MGM = grass silage + barley + maize gluten meal.

b $\mathrm{SEM}=$ standard error of the mean.

c $\mathrm{C} 1=$ control vs. other diets; $\mathrm{C} 2=\mathrm{FM}$ vs. SBM + MGM; C3 = SBM vs. MGM.

d Proportions of SMNAN and SDNAN expressed as $\mathrm{g} \mathrm{kg}^{-1}$ total microbial NAN (TMNAN) and $\mathrm{g} \mathrm{kg}^{-1}$ total dietary NAN (TDNAN), respectively.

tions of SNAN were affected by the diet as indicated by significant diet $\times$ time interaction. At 1 $\mathrm{h}$ post-feeding diet MGM had the highest (74.8 $\mathrm{mg} \mathrm{N}^{-1}$ ) concentration of free AA followed by diet SBM (Fig. 2). Free AA concentration for control and FM diets were higher at $0 \mathrm{~h}$ than in samples taken at $1 \mathrm{~h}$ post-feeding, and those for the other diets were also relatively high. Peptide $\mathrm{N}$ concentration in the liquid phase of digesta entering the omasum remained to be higher for protein supplemented-diets than that for control diet during the feeding cycle (Fig. 3).

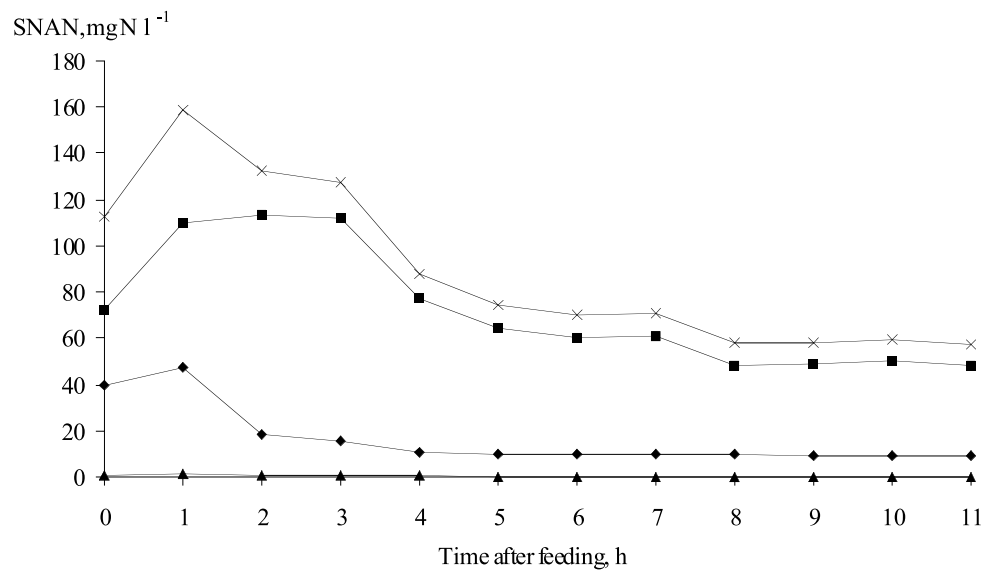

Fig. 1. Diurnal variations of nitrogenous fractions of soluble nonammonia $\mathrm{N}$ (SNAN) in the liquid phase of digesta entering the omasum during a $12 \mathrm{~h}$ feeding cycle $(\bullet=$ free amino acid; $\boldsymbol{\square}=$ peptide; $\boldsymbol{\Delta}=$ protein $; \times=$ total SNAN; standard error of the mean for the free amino acid, peptide, protein and total SNAN were 4.87, 9.36, 0.28 and 11.25 , respectively). 
Vol. 11 (2002): 79-91.

Fig. 2. Influence of dietary treatment on the extent of diurnal variation in free amino acid (AA) $\mathrm{N}$ of the liquid phase of digesta entering the omasum during a $12 \mathrm{~h}$ feeding cycle $(\diamond=$ grass silage + barley; $\mathbf{\square}=$ grass silage + barley + fishmeal; $\boldsymbol{\Delta}=$ grass silage + barley + soybean meal; $x=$ grass silage + barley + maize gluten meal; standard error of the mean for free AA N was 7.98).

Fig. 3. Influence of dietary treatment on the extent of diurnal variation in peptide $\mathrm{N}$ of the liquid phase of digesta entering the omasum during a $12 \mathrm{~h}$ feeding cycle $(\diamond=$ grass silage + barley; $\mathbf{q}=$ grass silage + barley + fishmeal; $\boldsymbol{\Delta}=$ grass silage + barley + soybean meal; $x=$ grass silage + barley + maize gluten meal; standard error of the mean for peptide $\mathrm{N}$ was 11.7).
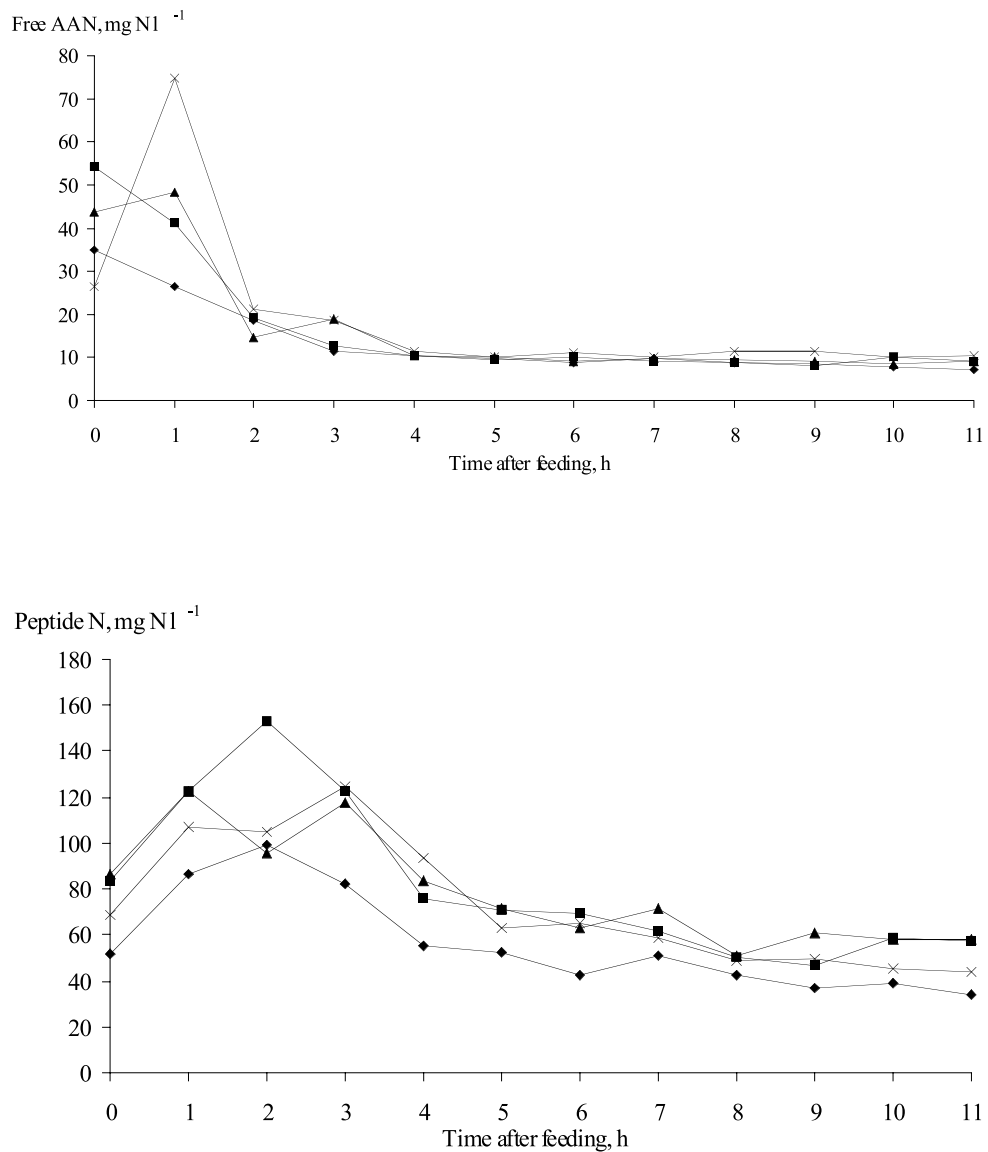

Peptide $\mathrm{N}$ concentration in omasal digesta peaked at $1 \mathrm{~h}$ (diet SBM), $2 \mathrm{~h}$ (control and FM diets) and $3 \mathrm{~h}$ (diet MGM) post-feeding and declined to the pre-feeding level.

\section{Discussion}

\section{Contribution of microbial $\mathrm{N}$ to total SNAN}

Previous studies have neglected the potential microbial contamination of SNAN (Chen et al. 1987a, b, Broderick and Wallace 1988). How- ever, extracellular AAs are probably excreted by rumen bacteria and protozoa cells or released during the cell lysis (Nolan 1993). Our recent study using ${ }^{15} \mathrm{~N}$ as a microbial marker suggested that a high proportion of SNAN in the liquid phase of digesta entering the omasal canal was of microbial origin (Choi et al. 2002a). It may also be partly explained by high concentration of glutamic acid, as an intermediate of bacterial AA metabolism, in free AA fraction of SNAN in omasal digesta (Choi et al. 2002a).

In the present study, ${ }^{15} \mathrm{~N}$ was also used to estimate microbial contamination of the liquid phase of digesta. The $\mathrm{NA}^{15} \mathrm{~N}$ was assumed to be entirely derived from liquid associated bacteria because engulfed LAB-NAN is spilled outside of protozoa cells (Jouany et al. 1988). The 


\section{Choi, C.W. et al. Protein response to omasal soluble non-ammonia nitrogen}

present microbial contribution to SNAN in the liquid phase of digesta (mean 0.64) is consistent with that of $0.63-0.86$ (Hristov and Broderick 1996) and of 0.61 (Choi et al. 2002a). The proportion of microbial contribution to the SNAN could, however, be overestimated as microbial lysis could have occurred during acid treatment of digesta and freezing after sampling.

Here, the microbial contribution to SNAN was similar to the microbial contribution to total NAN flow (mean 0.61). Besides, neither microbial NAN nor microbial SNAN were significantly affected by the supplements, supporting the previous result that rapeseed meal supplementation had no influence on microbial $\mathrm{N}$ flow in dairy cows (Ahvenjärvi et al. 1999). An increase of dietary SNAN by protein supplements may indicate that release of dietary $\mathrm{N}$ in the form of peptide and/or protein exceeds the proteolysis in the rumen. Consequently the peptide $\mathrm{N}$ could have an opportunity to escape the rumen and be absorbed in the small intestine as AA source by the host animal.

\section{Soluble NAN}

\section{Protein supplements}

Robinson et al. (1998) using dairy cows fed timothy silage, whole-crop barley silage and a mixed concentrate showed that protein supplements gave no significant increase in peptide $\mathrm{N}$ concentration in the liquid phase of ruminal digesta (mean 83.6 and $83.0 \mathrm{mg} \mathrm{N}^{-1}$ for without and with protein supplements, respectively). In the present study, peptide $\mathrm{N}$ concentration was, however, increased by protein supplements (mean 56.0 and $77.4 \mathrm{mg} \mathrm{N}^{-1}$ ). This is consistent with a considerable increase in peptide $\mathrm{N}$ flow from the rumen when the cows were fed grass silage based diets received protein supplements (Choi et al. 2002a, b).

Soybean meal has produced a higher SNAN concentration than other protein supplements e.g. maize gluten meal and/or blood meal (Robinson 1997) and fishmeal (Chen et al. 1987b) but not always (Williams and Cockburn 1991). Peptide $\mathrm{N}$ concentration in ruminal digesta at $1 \mathrm{~h}$ postfeeding was much higher for maize gluten meal than for fishmeal supplement (Williams and Cockburn 1991). However, the present concentration of peptide $\mathrm{N}$ and/or total SNAN was rather similar between protein supplemented-diets, even though the soluble $\mathrm{N}$ composition differed in protein feeds. Different peptide N concentrations on similar protein feeds between the studies could be influenced by variation in the quality of protein feeds, e.g. it is well known that the quality and composition of fishmeal can be different depending on a fish-drying and adding antioxidants (Mehrez et al. 1980). In addition, a rate of slowly degradable $\mathrm{N}$ fraction (b-fraction) is very different for experimental supplements, e.g. a rate $\left(\% \mathrm{~h}^{-1}\right)$ of $b$-fraction of soybean meal (9.4) is the fastest rate and that of maize gluten meal (2.3) is the slowest (NRC 2001). The similar peptide $\mathrm{N}$ concentration for the protein supplemented-diets supports the claim that peptide $\mathrm{N}$ concentration is poorly correlated with degradability and solubility of protein feeds (Williams and Cockburn 1991). Many studies have also shown that there was no difference in peptide $\mathrm{N}$ and SNAN concentration between diets containing different type of protein supplements (Chen et al. 1987b, Robinson and McQueen 1994, Choi et al. 2002b).

Here, protein supplements were replaced not by barley concentrate but by a part of control diet in order to keep grass silage to barley ratio (55:45) constant. However, the actual ratio of DM intake failed to keep the ratio planned (see Table 3), but it was still similar between the diets $(57: 43)$. The purpose of this was to allow to estimate SNAN flow in the liquid phase of omasal digesta per kg DM intake from the basal diet, and then calculate eSNAN from each protein supplement. Based on the equations 1-3, eSNAN was 49,22 and $37 \mathrm{~g} \mathrm{~kg}^{-1}$ of fishmeal, soybean meal and maize gluten meal, respectively.

Daily intake of soluble NAN in feed $\mathrm{N}$ of each protein supplement, calculated as soluble $\mathrm{NAN}$ in total $\mathrm{N}$ of protein feed $\times$ daily $\mathrm{N}$ intake of protein feed, appeared to be approx. 23, 28 


\section{AGRICULTURAL AND FOOD SCIENCE IN FINLAND}

Vol. 11 (2002): 79-91.

and $8 \mathrm{~g} \mathrm{~N} \mathrm{~d}^{-1}$ for fishmeal, soybean meal and maize gluten meal, respectively.

Overall, the eSNAN increased by each protein feed does not seem to be subjected to the intake of soluble NAN in protein feeds. The present results support our previous observation that the eSNAN is not related to a-fraction of in situ determination, and effective protein degradability can not necessarily be estimated as a sum of the escape calculated from $a$ - and $b$-fractions of in situ determination (Choi et al. 2002b).

\section{Metabolism of SNAN}

Wallace and McKain (1990) reported that a colourimetric method using ninhydrin does not give estimate of peptide concentration reliably because of extremely high ammonia concentration in acid-hydrolysates after alkaline-heating. We have also observed markedly high ammonia in samples after the acid-hydrolysis (Choi et al. 2002a). However, our preliminary analysis showed that proportionately 0.99 of ammonia in the pre-hydrolysis samples was eliminated by the alkaline-heating method. Therefore, in the present study, SNAN obtained in the acid-hydrolysates was corrected for ammonia $\mathrm{N}$ concentration determined in the pre-hydrolysis.

In the present study, markedly higher peptide $\mathrm{N}$ in total SNAN than the other two fractions is consistent with the previous observation of high peptide $\mathrm{N}$ in ruminal fluid (Chen et al. 1987a, Choi et al. 2002b) and in omasal fluid (Choi et al. 2002a, b). Free AA concentration in ruminal digesta is relatively low (Williams and Cockburn 1991) even during the period immediately post-feeding (see Nolan 1993). However, in the present study, free AA concentration in omasal digesta was relatively high immediately post-feeding. On an average, the present free AA concentration is consistent with our previous results (mean $15.3 \mathrm{mg} \mathrm{N}^{-1}$ ) (Choi et al. 2002a). In the diurnal pattern of free AA in the present study, the reason for the lacks of the peaks for control and FM diets was unclear (Fig. 2). However, although many studies reported clear peaks in free AA concentration (Broderick and Wallace 1988, Choi et al. 2002b), some pro- tein supplements produced the constant diurnal pattern without peaks in free AA concentration (Choi et al. 2002a). Extremely low soluble protein fraction of SNAN in the present study is consistent with other studies, in which different protein supplements were given (Williams and Cockburn 1991, Choi et al. 2002b). The low soluble protein $\mathrm{N}$ could be explicated by that soluble protein in feed $\mathrm{N}$ is rapidly degraded to nonprecipitable peptides (Choi et al. 2002b). Partitioning of SNAN fractions may be less important as regards to determination of the supply of AA from soluble $\mathrm{N}$ fraction, since all $\mathrm{N}$ fractions are assumed to be completely digested in the small intestine.

Concentrations of peptide $\mathrm{N}$ varied between 82 and $111 \mathrm{mg} \mathrm{N}^{-1}$ (Chen et al. 1987a, b, Robinson and McQueen 1994, Robinson et al. 1998). The present peptide $\mathrm{N}$ concentration in omasal fluid (mean $72 \mathrm{mg} \mathrm{N}^{-1}$ ) was marginally lower than the values reported previously. However, the previous peptide concentrations included free AA (Robinson and McQueen 1994, Robinson et al. 1998) since free AA fraction was not determined before hydrolysis. Taking this into account, the sum of peptide and free AA concentration for control, FM, SBM and MGM was 70, 98, 95 and $92 \mathrm{mg} \mathrm{N}^{-1}$, respectively, estimates that are in good agreement with the reported values. Our most recent study showed that peptide $\mathrm{N}$ concentration excluding free AA in omasal digesta was $54-64 \mathrm{mg} \mathrm{N}^{-}$ ${ }^{1}$ when protein supplements were given to cows (Choi et al. 2002b). Diurnal pattern in ruminal or omasal peptide concentration (and/or total SNAN) that peaked immediately post-feeding and declined thereafter has been observed in many studies (Chen et al. 1987a, Williams and Cockburn 1991, Robinson et al. 1998, Choi et al. 2002a, b). When ryegrass hay and maize based concentrate were fed with urea or ovalbumin diurnal pattern in peptide concentration in the rumen was rather constant (Broderick and Wallace 1988). In their study, however, ruminal peptide $\mathrm{N}$ reached a maximum immediately post-feeding, when the diet was supplemented with casein. 
Choi, C.W. et al. Protein response to omasal soluble non-ammonia nitrogen

\section{Conclusions}

Present data confirm the previous observation (Choi et al. 2002a) that a substantial proportion of SNAN in the liquid phase of omasal digesta can escape ruminal degradation. Protein supplements increased peptide $\mathrm{N}$ and total SNAN fractions in the liquid phase of omasal digesta, whereas there were not differences in the SNAN concentration between different protein supplements. The omasal SNAN provided by protein feeds was not equated with soluble $\mathrm{N}$ the pro- tein feeds. Quantitatively peptides rather than free AA or soluble protein were the most important $\mathrm{N}$ fraction of SNAN in the liquid phase of digesta. The potential microbial contribution to SNAN in omasal digesta using ${ }^{15} \mathrm{~N}$ as a microbial marker suggested that the SNAN was substantially contaminated by microbes.

Acknowledgements. The authors thank Mrs A. Matilainen and her staff for care of experimental animals and $\mathrm{Mr} \mathrm{V}$. Toivonen and his laboratory staff for chemical analyses. C.W. Choi appreciates the financial support of the Agricultural Research Foundation of August Johannes and Aino Tiura.

\section{References}

Ahvenjärvi, S., Vanhatalo, A., Huhtanen, P. \& Varvikko, T. 1999. Effects of supplementation of a grass silage and barley diet with urea, rapeseed meal and heatmoisture-treated rapeseed cake on omasal digesta flow and milk production in lactating dairy cows. Acta Agriculturæ Scandinavica Section A, Animal Science 49: 179-189.

Ahvenjärvi, S., Vanhatalo, A., Huhtanen, P. \& Varvikko, T. 2000. Determination of reticulo-rumen and wholestomach digestion in lactating cows by omasal canal or duodenal sampling. British Journal of Nutrition 83: $67-77$.

AOAC 1990. Official methods of Analysis. 15th ed. Association of Official Analytical Chemists, AOAC, Arlington, VA. USA.

Broderick, G.A. 1987. Determination of protein degradation rates using a rumen in vitro system containing inhibitors of microbial nitrogen metabolism. British Journal of Nutrition 58: 463-475.

Broderick, G.A. \& Wallace, R.J. 1988. Effects of dietary nitrogen source on concentrations of ammonia, free amino acids and fluorescamine-reactive peptides in the sheep rumen. Journal of Animal Science 66: 2233-2238.

Chen, G., Russell, J.B. \& Sniffen, C.J. 1987a. A procedure for measuring peptides in rumen fluid and evidence that peptide uptake can be a rate-limiting step in ruminal protein degradation. Journal of Dairy Science 70: 1211-1219.

Chen, G., Sniffen, C.J. \& Russell, J.B. 1987b. Concentration and estimated flow of peptides from the rumen of dairy cattle. Effects of protein quantity, protein solubility, and feeding frequency. Journal of Dairy Science 70: 983-992.

Choi, C.W., Ahvenjärvi, S., Vanhatalo, A., Toivonen, V. \& Huhtanen, P. 2002a. Quantitation of the flow of solu- ble non-ammonia nitrogen entering the omasal canal of dairy cows fed grass silage based diets. Animal Feed Science and Technology 96: 203-220.

Choi, C.W., Vanhatalo, A., Ahvenjärvi, S. \& Huhtanen, P. $2002 b$. Effects of several protein supplements on flow of soluble non-ammonia nitrogen from the forestomach and milk production in dairy cows. Animal Feed Science and Technology (In press).

Firkins, J.L., Berger, L.L., Merchen, N.R., Fahey, G.C., Jr. \& Mulvaney, R.L. 1987. Ruminal nitrogen metabolism in steers as affected by feed intake and dietary urea concentration. Journal of Dairy Science 70 : 2302-2311.

France, J. \& Siddons, R.C. 1986. Determination of digesta flow by continuous marker infusion. Journal of Theoretical Biology 121: 105-119.

Hristov, A. \& Broderick, G.A. 1996. Synthesis of microbial protein in ruminally cannulated cows fed alfalfa silage, alfalfa hay, or corn silage. Journal of Dairy Science 79: 1627-1637.

Jouany, J.P., Demeyer, D.I. \& Grain, J. 1988. Effect of defaunating the rumen. Animal Feed Science and Technology 21: 229-265.

Korhonen, M., Vanhatalo, A. \& Huhtanen, P. 2002. Effect of protein source on amino acid supply, milk production, and metabolism of plasma nutrients in dairy cows fed grass silage. Journal of Dairy Science (In press).

Licitra, G., Hernandez, T.M. \& Van Soest, P.J. 1996. Standardization of procedures for nitrogen fractionation of ruminant feeds. Animal Feed Science and Technology 57: 347-358.

McCullough, H. 1967. The determination of ammonia in whole blood by a direct colorimetric method. Clinica Chimica Acta 17: 297-304.

Mehrez, A.Z., Ørskov, E.R. \& Opstvedt, J. 1980. Process- 
Vol. 11 (2002): 79-91.

ing factors affecting degradability of fish meal in the rumen. Journal of Animal Science 50: 737-744.

Nolan, J.V. 1993. Nitrogen kinetics. In: Forbes, J.M. \& France, J. (eds.). Quantitative aspects of ruminant digestion and metabolism. CAB International Wallingford, Oxon, UK. p. 123-143.

NRC 2001. Nutrient Requirements of Dairy Cattle. 7th rev ed. National Research Council. National Academy Press, Washington, D.C. USA.

Robinson, P.H. 1997. Modifying duodenal flow of amino acids by manipulation of dietary protein sources. Canadian Journal of Animal Science 77: 241-251.

Robinson, P.H. \& McQueen, R.E. 1994. Influence of supplemental protein source and feeding frequency on rumen fermentation and performance in dairy cows. Journal of Dairy Science 77: 1340-1353.

Robinson, P.H., Veira, D.M. \& Ivan, M. 1998. Influence of supplemental protein quality on rumen fermentation, rumen microbial yield, forestomach digestion, and intestinal amino acid flow in late lactation Holstein cows. Canadian Journal of Animal Science 78: 95-105.

SAS 1996. Statistical Analysis System. Release 6.12. SAS Institute Inc., Cary, NC, USA.

Van Soest, P.J., Robertson J.B. \& Lewis, B.A. 1991. Methods for dietary fiber, neutral detergent fiber and nonstarch polysaccharides in relation to animal nutrition. Journal of Dairy Science 74: 3583-3597.

Wallace, R.J. \& McKain, N. 1990. A comparison of methods for determining the concentration of extracellular peptides in rumen fluid of sheep. Journal of Agriculture Science, Cambridge 114: 101-105.

Williams, A.P. \& Cockburn, J.E. 1991. Effect of slowly and rapidly degraded protein sources on the concentrations of amino acids and peptides in the rumen of steers. Journal of the Science of Food and Agriculture 56: 303-314.

\title{
SELOSTUS
}

\section{Valkuaistäydennyksen vaikutus lypsylehmän pötsistä virtaavan liukoisen rehuperäisen typen pitoisuuteen ja määrään säilörehuruokinnalla}

\author{
Chang Weon Choi, Aila Vanhatalo ja Pekka Huhtanen \\ MTT (Maa- ja elintarviketalouden tutkimuskeskus)
}

Valkuaistäydennyksen vaikutusta lypsylehmän pötsis-
tä virtaavan liukoisen rehuperäisen typen $(\mathrm{N})$ pitoi-
suuteen ja määrään tutkittiin $4 \times 4$ latinalaisen neli-
ön koemallin mukaisessa kokeessa. Koe-eläiminä oli
neljä pötsifistelöityä lypsylehmää, jotka saivat kont-
rolliruokinnalla nurmisäilörehua ja ohraa siten, että
syönti oli $95 \%$ vapaasta syönnistä ja säilörehun ja
ohran suhde oli 55:45. Muilla ruokinnoilla perusre-
huja korvattiin kalajauholla (6\%), soijarouheella
$(9 \%)$ ja maissigluteenilla (6 \%) siten, että ohran ja
säilörehun suhteelliset osuudet pysyivät vakioina ja
valkuaistäydennyksenä tulevan typen määrä oli sama
kaikilla valkuaisrehuilla.
Valkuaistäydennys lisäsi pötsistä virtaavan pep-
tidi-N:n ja liukoisen rehuperäisen $\mathrm{N}: \mathrm{n}$ pitoisuuksia satakerran ruokasulassa, mutta erot valkuaisrehujen välillä olivat pieniä. Peptidi-N muodosti suurimman osan liukoisesta rehuperäisestä $\mathrm{N}$ :stä osoittaen, että peptidien hydrolyysi aminohapoiksi on rajoittavin vaihe pötsin proteolyysissä. Mikrobi-N:n osuus liukoisesta rehuperäisestä N:stä oli 0,64 osoittaen, että suuri osa satakertaan virtaavasta rehuperäisestä liukoisesta N:stä oli mikrobista alkuperää. Laskelma liukoisen rehuperäisen $\mathrm{N}$ :n virtauksesta syötyä kuivaainekiloa kohti osoitti, että kalajauhosta $\mathrm{n} .49 \mathrm{~g} \mathrm{~kg}^{-1}$, soijarouheesta n. $22 \mathrm{~g} \mathrm{~kg}^{-1}$ ja maissigluteenista n. $37 \mathrm{~g} \mathrm{~kg}^{-1}$ virtasi ulos pötsistä hajoamatta liukoisessa muodossa. 